DOSSIER THÉMATIQUE 1

SIUE DEUS SIUE DEA. DÉNOMINATIONS DIVINES DANS LES MONDES GREC ET SÉMITIQUE : UNE APPROCHE PAR LE GENRE

1 Corinne Bonnet, Thomas Galoppin, Adeline Grand-ClÉment

Que fait le genre aux dénominations divines, entre mondes grecs et sémitiques?

17 Stella GEORGOUDI

Qu'est-ce qu'une «Grande » (Megalê) divinité en Grèce ancienne ?

32 Stéphanie ANTHONIOZ

Noms et corps divins dans les textes bibliques : une approche par le genre

42 Audrey VASSELIN

De la bonne manière de nommer Athéna à Athènes :

I'emploi de hê theos dans les inscriptions athéniennes (VIe-IVe siècles av. J.-C.)

54 Aleksandra KUBIAK-SCHNEIDER

Women in the votive dedications from Palmyra

65 Marie AUgIER

Dénominations divines, genre des acteurs du rituel et des agents cultuels : le cas des prêtrises de Dionysos

84 Adriano ORSINGHER

Giving a face to a name. Phoenician and Punic Divine Iconographies, Names and Gender

98 DOSSIER THÉMATIQUE 2

TRADITION ET TRANSMISSION DANS L'ANTIQUITÉ : RÉFLEXIONS INTERDISCIPLINAIRES

159 ACTUALITÉ DE LA RECHERCHE

QUOI DE NEUF À L'OUEST DE STRASBOURG ? KOENIGSHOFFEN :

ÉTAT DES LIEUX ET DÉCOUVERTES RÉCENTES

195 VARIA 


\title{
WOMEN IN THE VOTIVE DEDICATIONS FROM PALMYRA
}

\author{
Aleksandra KUBIAK-SCHNEIDER \\ Post-doctorant in history of religions \\ Université Toulouse 2 - Jean Jaurès \\ ERC Mapping Ancient Polytheisms (MAP - 741182) \\ EA 4601 PLH-ERASME \\ okubiak@gmail.com
}

\section{RÉSUMÉ}

Les données épigraphiques et iconographiques de Palmyre éclairent les rôles des femmes dans la vie religieuse. Cet article présente les occurrences à travers l'approche du genre comprise comme une construction culturelle et linguistique. La grammaire des dédicaces araméennes montre les dédicants qui font I'offrande et les dieux à qui elle est faite. On prend en compte dans cet article le genre des divinités à qui les femmes s'adressent dans leurs prières et auprès desquelles les noms de ces femmes apparaissent. Elles y sont présentées comme filles, femmes et sœurs, quand les hommes figurent comme fils, maris, frères et oncles. Enfin, on pose la question de l'existence des prêtresses, fonction sur laquelle les textes restent muets. Dans ce contexte, on peut se demander si quelques prétendues tribus palmyréniennes ne pourraient être des associations cultuelles, lesquelles mentionnent des membres féminins (bnt). Les sources iconographiques des temples de Bel et d'Allat montrent l'image étrange de femmes entièrement voilées assistant aux fêtes : peut-on y voir des prêtresses?
The epigraphic and iconographical data from Palmyra shed light on the roles of women in the religious life. This article presents the evidence using the concept of gender, understood as a cultural and a linguistic construct. The grammar of the Aramaic dedications indicates the gender of the divinities and of their worshippers. We study the gods, uniquely masculine, to whom women address their prayers. We take a look at the presentation of women in the inscriptions, who often give their family affiliations, such as: daughters, wives, sisters, while men present themselves as sons, fathers, brothers, husbands and uncles. In the end, we raise the question of priestesses, because sources remain mute about such a cultic function. In this context, we may wonder whether some of the so-called tribes could not rather be cultic associations mentioning their female members (bnt). The iconographic sources from the temples of Bel and of Allat show a strange depiction of entirely veiled women attending festivals: is it possible to associate them to priestesshood?
KEYWORDS

Palmyra, epigraphy, iconography, Aramaic,

Roman Near East, history of religions, gender. 
Palmyra, the ancient city situated in the Syrian Desert on the route between Homs to the West and Euphrates to the East, still impresses with its ruins, despite of recent demolition by terrorists. The remains - sanctuaries, colonnade streets, tombs, theatre - are mostly dated to the $1^{\text {st }}$ to $3^{\text {rd }}$ centuries $C E$, a period of fame and splendour for the city. [1] The grandeur of Palmyra lies in the cooperation with the Roman Empire which brought several privileges, like the status of a free city, thanks to the long-distance trade with luxurious goods (silk, incense, etc.) operated by caravans sent with financial support by its citizens. The city provides us with an impressive evidence of preserved inscriptions: over 2500 texts written in a local dialect and script of Aramaic, some of which are GrecoAramaic bilingual or even a few trilingual in Latin, Greek and Aramaic. Among the texts we find honorific inscriptions commemorating outstanding merits of citizens, votive dedications praising the good deeds of divinities, construction texts of the main sanctuaries and of tombs, funerary epitaphs with names of Palmyrenes, legends of tesserae (small clay objects related to temple activities, currently considered as invitations to cultic banquets). [2] Such an abundance of epigraphic material provides an outline of the different spheres of life of the inhabitants of Palmyra. Beside the epitaphs, texts referring to cults and gods form a rich group of inscriptions. The religious inscriptions attest divinities, such as Bel, Nabu, Yarhibol, Aglibol, Baalshamin, Allat, Ashtarte, etc. dwelling in the sanctuaries dispersed in the city. But these gods would not exist without their worshippers, also mentioned in the inscriptions from Palmyra. The preserved epigraphic evidence presents an overview of the roles of both male and female participants in rituals.

Men are frequently attested in the epigraphic sources from Palmyra, as well as other Near Eastern cities [3] of the imperial period, appearing, seemingly, as the privileged group of agents in ritual practices. The image of a Palmyrene priest is recognizable in the art by his characteristic conical hat, usually called modius, [4] and completed by a plethora of inscriptions, especially on the tesserae. Women are much less attested than men in texts and images related to the religious life of Palmyra. Women are much more visible in the funerary portraiture, so in the private context, than in the religious evidence. [5] The disproportion is striking, as there are numerous funerary reliefs, but only a few reliefs depicting scenes of offerings, feasts, etc.

Even recently, the issue of women in Palmyra has been repeatedly addressed in scholarly discussions. It is enough to mention the latest works of $\mathrm{E}$. Cussini, C. Finlayson, M. Hayn, S. Krag, S. Klaver and J.-B. Yon who shed a new light on the subject. [6]
[1] Later remains in Palmyra exist, for example, with a military camp and churches installed in the city from the $4^{\text {th }}$ century CE onwards. For the late antique Palmyra see INTAGLIATA 2018 who gives an overview of the city after 273 $\mathrm{CE}$, the year of a sack of Palmyra by the Roman emperor Aurelian after the revolt of Zenobia and her son Wahballat. The Aurelian's raid on the city is considered to mark the end of the city. The study by Intagliata clearly shows that despite serious damages in some parts of the city and a halt in the construction of buildings, the total destruction of the city is only a myth propagated by the Historia Augusta Vita Aureliani, an ancient historic source describing the reign and actions of Aurelian. For details on the history of Palmyra, see recently SOMMER 2018.

[2] RAJA 2015 and 2016.

[3] I am aware that the same situation is also found beyond this region, but I would like to stay focused on one fragment, relatively vast, of the Graeco-Roman world.

[4] A term contested in RAJA 2017.

[5] The division on the religious and funerary epigraphic material relies on the definition of the former as all texts related to the gods, sanctuaries, cults and festivals celebrated in their honour, while the latter concerns the burial traditions, tombs and epitaphs. This paper omits the question of the funerary portraits and inscriptions, so as not to infringe on the recent and exhaustive work of S. Krag. This is not a paper about women in Palmyra in general, but in the religious context.

[6] CUSSINI 2005 provides a quick overview of the position of women in the Palmyrene religions; FINLAYSON 2013 presents an archaeological evidence of the ritual and cultic roles of Palmyrene women; HEYN 2019 analyses gestures of women on the votive reliefs; KRAG 2017 presents the social role of women and children in the Palmyrene society through the funerary material; KLAVER 2019b speaks about the costumes of women and their probable cultic function; YON 2018 turns her attention to the keys held by women in funerary portraits, and their relation to the religions of Palmyra. All these papers complete each other and constitute a good basis for the social history of women in Palmyrene rituals. 
This paper uses an approach based on gender and its social construction to better understand the perception of the roles of men and women in the Palmyrene society within the religious sphere. Beyond the biological sex, gender is defined by the cultural, social and psychological traits. [7] Moreover, the construction of gender is stressed foremost in the language which "is considered the building block of culture; it conveys meaning and creates the system of knowledge humans participate in. Ultimately, language has a huge influence on how humans perceive reality and, as a result, is the creator of this reality". [8] We cannot underestimate the linguistics, especially morphology and syntax, in the studies with a gender approach. The grammatical rules defined for each language, comprising the distinction between grammatical genders (masculine, feminine and neutral) of nouns, adjectives, pronouns and sometimes verbs, influence the perception of the world. It is in this spectrum that I will deal with a Palmyrene material composed mostly of the votive inscriptions, the texts which - apart from the epitaphs - mention in a great number the female representants of the Palmyrene society. Beside the votive context, we count only a few examples of women in honorific inscriptions, which will be discussed in the second section of this paper. It is striking, however, that the textual evidence of female participation in cults is practically limited to one sort of inscriptions. We also have a few iconographic representations showing women as participants or actors in the rituals in Palmyra (see section 3 below).
The ritual agents, whatever their gender, are responsible for the proper communication between gods and humans. They set the rules on how to address and to refer to the divinities. What interests me in the study proposed in this paper is the definition of women and men in the inscriptions and in the visual arts of Palmyra related to the religious sphere, the relations between women, men and both genders toward the gods and finally the question of priesthood: can we identify any priestess in Palmyra?

\section{PALMYRENE WOMEN PRAISING AND ACKNOWLEDGING THE DIVINE}

Interestingly enough, we find no dedication made by a woman to any female divinity in our documentation. We do not have any epigraphic attestation of female names related to the cult of Allat or Atargatis, who had their sanctuaries in Palmyra. For the time being, I am not able to provide any answer to this intriguing question; it may just be due to a lack of chance with the epigraphic sources. The situation is different in Dura-Europos, a Syrian city located on the Euphrates where a significant community of Palmyrenes lived: there, we know that women took part in the cult of Artemis, since their names were written on the steps in the Salle-à-gradins next to the temple of the goddess (fig. 1). [9] In Palmyra, we only have evidence of women dedicating to male divinities.

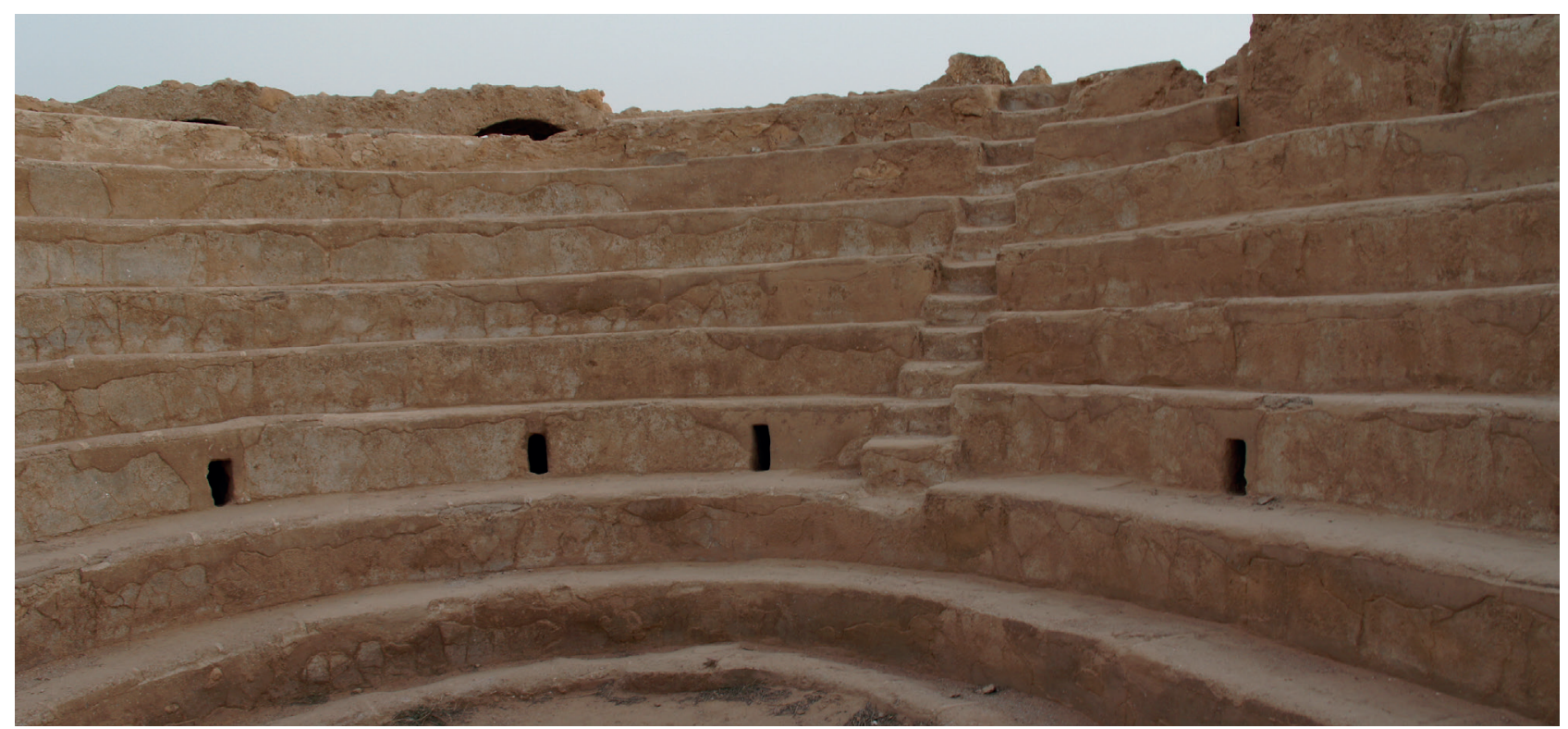

Fig. 1 : Tiered room (salle-à-gradins), Doura-Europos.

[7] LINDSEY 2015, p. 4.

[8] LINDSEY 2015, p. 4.
[9] Duchateau 2013, p. 196-198, Klaver 2019b, p. 35-37. Both publications provide and summarize the research on this particular temple. 
A large number of women appear in the dedications specified with the formula: "Blessed his name forever" (bryk šmh I'Im') or ("May his name be blessed forever": Ibryk šmh ('Im'), and in some inscriptions addressed to the god called simply "the Merciful" (rhmn'), written on stone altars of medium size and dating mostly from the period of the $2^{\text {nd }}$ and $3^{\text {rd }} \mathrm{C}$. CE. This material is remarkable on the scale of the Palmyrene epigraphy, not as a specific cult as it was stated before 2016 [10], but as an alternative way of doing a thanksgiving to a favourable deity. It puts the accent on acclaiming his eternal glory, a habit attested rather in hymns and prayers than in the short votive inscriptions. [11] The number of votive dedications mentioning a specific divine theonym [12] does not equal the frequency of use of the above formula. Texts referring to the specific proper name of a god are less frequent in the evidence than the ones containing the praise expression. It might be explained simply by the fact that the expression "Blessed his name forever" had a universal character and would have been applied to any male divinity who answered to the supplications. [13] The form of this formula clearly indicates a male deity: implied by the masculine suffix $-h$ of the $3^{\text {rd }}$ person sing. attached to the word šm, name: šmh putting a strong accent on His name and not on Her name (-hy). The same observation is relevant to rhmn, "the Merciful" which is a substantive adjective in masculine form. The epithets used in those inscriptions, such as "good" and "compassionate", are masculine as well.

Table 1. presents 20 cases which explicitly mention women in the role of a dedicator or a co-dedicator, acting together with other members of their families.

\begin{tabular}{|c|c|c|c|c|}
\hline $\mathbf{N r}$ & Corpus [14] & Datation & $\begin{array}{l}\text { Dedicant name and } \\
\text { affiliation }\end{array}$ & Deity \\
\hline 1 & PAT 0065 & $2^{\text {nd }} / 3^{\text {rd }}$ C. CE & Aqmat, daughter of Male & $\begin{array}{l}\text { Great Lord of all Living Creatures } \\
\text { whose name may be blessed forever }\end{array}$ \\
\hline 2 & PAT 0352 & $178 / 9 \mathrm{CE}$ & ?, daughter of Zabdibel & May his name be blessed forever \\
\hline 3 & PAT 0356 & $9 \mathrm{Ab} 192 \mathrm{CE}$ & Ale, daughter of Zebeida & May his name be blessed forever \\
\hline 4 & PAT 0360 & 207 CE & $\begin{array}{l}\text { Makkai, daughter of } \\
\text { Ogga, wife of Male }\end{array}$ & $\begin{array}{l}\text { May his name be blessed forever, } \\
\text { good and merciful }\end{array}$ \\
\hline 5 & PAT 0366 & $210+C E$ & $\begin{array}{l}\text { Domnina, daughter of } \\
\text { Yediabel }\end{array}$ & $\begin{array}{l}\text { May his name be blessed forever, } \\
\text { good and merciful }\end{array}$ \\
\hline 6 & PAT 0373 & $230 \mathrm{CE}$ & $\begin{array}{l}\text { Betzabideh, daughter of } \\
\text { Gadarsu }\end{array}$ & $\begin{array}{l}\text { May his name be blessed forever, } \\
\text { good and merciful }\end{array}$ \\
\hline 7 & PAT 0394 & 263/4 CE & $\begin{array}{l}\text { Qushai, daughter of } \\
\text { Seleukos and Shebtai, } \\
\text { daughter of Wahballat }\end{array}$ & Blessed his name forever \\
\hline 8 & PAT 0413 & $2^{\text {nd }} / 3^{\text {rd }}$ C. CE & $\begin{array}{l}\text { Mazba, daughter of } \\
\text { Mazbana }\end{array}$ & Blessed his name forever \\
\hline 9 & PAT 0426 & $2^{\text {nd }} / 3^{\text {rd }}$ C. CE & Hadira, daughter of ? & May his name be blessed forever \\
\hline 10 & PAT 0429 & $2^{\text {nd }} / 3^{\text {rd }}$ C. CE & $\begin{array}{l}\text { Shalmat, daughter of } \\
\text { Elah }\end{array}$ & Blessed his name forever \\
\hline 11 & PAT 0433 & $2^{\text {nd }} / 3^{\text {rd }}$ C. CE &. $\mathrm{RBN}^{\prime}$ & Blessed his name forever \\
\hline 12 & PAT 1001 & 233 CE & $\begin{array}{l}\text { Ate, wife of Yarhibola and } \\
\text { Shalom, their daughter }\end{array}$ & $\begin{array}{l}\text { Blessed his name forever, good and } \\
\text { merciful. }\end{array}$ \\
\hline
\end{tabular}

[10] E.g. TEIXIDor 1979, GaWLikowsKi 1990.

[11] Our paper does not deal with the issue of either the deity behind the formulas or the cult itself. For more details, see: KubiaK 2016, KUBIAK-SCHNEIDER in press. In the votive dedications we would rather expect theonyms (divine names) to whom these texts are addressed. Palmyra delivers both examples: the dedications with given formula and the proper names of the Palmyrene gods (Bel, Nabu, Manawat, Allat, Baalshamin, Yarhibol, etc.). For the gods in Palmyra see among others GAWLIKOWSKI 1990 and KAIZER 2002.
[12] Gods such as (among others) Bel, Baalshamin, Nabu, Nergal, Arsu, Yarhibol, Aglibol, Malakbel, Abgal, Shalman, Shamash, Maanu are worshipped in Palmyra and their names appear in the votive and honorific inscriptions and in the legends of tesserae. Only the name of Bel is more frequent in the honorific texts and on the tesserae, but not in the votive evidence.

[13] Kubiak 2016, p. 344 and 347.

[14] The table follows the numbers of an epigraphic corpus, mostly PAT, as the chronology is not really clear. 


\begin{tabular}{|c|c|c|c|c|}
\hline 13 & PAT 1434 & $165 \mathrm{CE}$ & $\begin{array}{l}\text { Tadel, freedwoman of } \\
\text { Bassos, son of Maanu }\end{array}$ & May his name be blessed forever \\
\hline 14 & PAT 1911 & $251 \mathrm{CE}$ & Ada, wife of Narai & $\begin{array}{l}\text { May his name be blessed forever, } \\
\text { merciful and compassionate }\end{array}$ \\
\hline 15 & PAT 1915 & $2^{\text {nd }} / 3^{\text {rd }}$ C. CE & Aqmat & Eternal blessing of his name \\
\hline 16 & PAT 2635 & $2^{\text {nd }} / 3^{\text {rd }}$ C. CE & Belta, wife of Natan & $\begin{array}{l}\text { Blessed his name forever, good and } \\
\text { merciful }\end{array}$ \\
\hline 17 & IMP 9 & 18 Qenian $251 \mathrm{CE}$ & $\begin{array}{l}\text { Bolaia Betnesa, daughter } \\
\text { of Baraa }\end{array}$ & $\begin{array}{l}\text { Blessed his name forever, the } \\
\text { Merciful, good. }\end{array}$ \\
\hline 18 & SP $10,1$. & $2^{\text {nd }} / 3^{\text {rd }}$ C. CE & Hanita, sister of Hannur & Blessed his name, the Merciful. \\
\hline 19 & SP $10,8$. & $2^{\text {nd }} / 3^{\text {rd }}$ C. CE & $\begin{array}{l}\text { Dama, daughter of } \\
\text { Belhazai }\end{array}$ & $\begin{array}{l}\text { My blessing to his name forever, the } \\
\text { Merciful, good. }\end{array}$ \\
\hline 20 & Sem 52-53, 8 & $2^{\text {nd }} / 3^{\text {rd }} c \cdot C E$ & $\begin{array}{l}\text { Nabushai, daughter of } \\
\text { Lishamsh }\end{array}$ & May his name be blessed \\
\hline
\end{tabular}

All dedications contain the quoted formula, while three of them equate the Blessed name with the Merciful and one is addressed in particular to the Lord of all Living Creatures. [15] A research made before 2016 [16] stressed that this number of texts testifies that women were particularly keen on addressing their dedications to the so-called Anonymous God of Palmyra. [17] This hypothesis loses its strength when compared to the similar corpus of votive inscriptions from beyond Palmyra, both in Semitic and Greek, where women play the role of agents in the same way as men. [18] In these 21 texts, as well as in the dedications to other gods, female dedicants present themselves as daughters (in most of the cases) or wives of a male representative of their families. [19] Two women, however, do not mention their affiliation. The lack of familial attachments is also present in the dedications made by men, like the text PAT 0442 from the $2^{\text {nd }}$ or $3^{\text {rd }}$ C. CE, dedicated by a man called Zabod in praise of the good god's name forever (Ibryk šmh I'Im' th'). Scholars usually claim that foreigners did not give their affiliation, [20] but it seems to me that the mention of the family in votive texts was a matter of personal choice rather than a formal requirement.

[15] KuBiaK-SCHNEIDER 2021.

[16] KUBIAK-SCHNEIDER 2021.

[17] Dirven 1999, p. 169, Cussini 2005, p. 29-30, Yon 2002. This female tendency is deduced by these authors from the frequency of the appearance of female names among the dedicators. Moreover, the quoted formula was considered until 2016 as a reference to a single deity from the Palmyrene religions. The term "Anonymous God" is obsolete nowadays and does not correspond to the ancient concept of the divinities worshipped in Palmyra, so it does not imply a specific cult in the religious dynamics of this Syrian city. It is a local feature of use of the praise formula, known from a ritual text, to glorify the divine favours, and
Most of the dedicants are male individuals, though (total: 169 texts with the formula bryk šmh I'Im' and 22 texts with rhmn'). Among the inscriptions which provide us with female names we also find some texts where entire families made the dedications. [21] See for instance PAT 1911, dated from 251 CE:

"May his name be blessed forever, merciful and compassionate (Ibryk šmh I'Im' rhmn' wtyr'), in thanksgiving ( $m w d^{\prime}$ ) Naarai, son (br) of Moqimu Titus Iulius, and Ada, his wife ('tth), and his children (bnwh), and all associated to his house (bny byth klhwn), because they called upon him in distress $\left(b^{\prime} q^{\prime}\right)$ and he answered in serenity (brwh'). Year $251 \mathrm{CE}$, month Nisan".

The word bnwh should be translated in English as "his sons", but in this plural form it also has a more generic meaning, "his children", comprising also the female offspring, but not marked in this case. From a gender point of view, it is interesting to note that the collective is always designed in the masculine form without specification of "daughters".

The way women address gods in thanksgiving is not different from the way men do: there is no difference in the vocabulary between the dedications made by

has a more universal sense which could be applied to many male divinities in Palmyra. The anonymity postulated in the history of the research on Palmyrene religious life does not match the accent put on the eternal praise of HIS name, cf. supra and KAIZER 2019, p. 23.

[18] The corpora of inscriptions and some studies reveal the number of votive texts made by women and by men, and here is no place to cite them. See the examples from the Semitic context in BeYER 1998 and, from the Greek side, SCHÖRNER 2003.

[19] Yon 2018, p. 185.

[20] Yon 2002, p. 97.

[21] Such as the text PAT 0394. 
men, by women and by entire families. This is also true if we consider votive inscriptions in general: they remain similar whatever the gender of the dedicant is. For instance, we may compare the inscription PAT 1908 made by a man with another dedication made by a woman, such as PAT 0373:

PAT 1908 "Blessed his name forever, good ( $t b$ ') and merciful. Made ( $\boldsymbol{b} \boldsymbol{d} \boldsymbol{d})$ in thanksgiving ( $m w d$ ') by Malku and 'Ataai, sons of Haggegu, son of Malku Zuzai for they life and the life of their children. In the month of Elul ('/Wl), year $241 \mathrm{CE}$ '.

vs.

PAT 0373 "May his name be blessed forever, good and merciful, made ('bdt) Batzabideh, daughter (brt) of Gaddarsu for her life and the life of 'Obaidu, her husband ( $\left.b^{\prime} / h\right)$. In the month of Ab, year 230 CE." As these examples show, the grammatical forms of verbs agree to the gender of the dedicator.

In order to better grasp the relations between Palmyrene women and gods, it is interesting to pay attention to the theophoric female anthroponyms. [22] Among the names of female dedicators, only four are undoubtedly theophoric: Shalmat, which is a divine name used as an anthroponym, Shalmallat ("Peace by Allat"), Belta ("Lady" - cultic title of Zarpanitu, wife of Bel-Marduk, worshipped in Palmyra) and Hanita ("Athe is gracious"). The first two names are epicene, used by women as well as men in unchanged grammatical forms.

If we turn to the social functions of the named women, we do not find any further information about their profession or activity in the votive inscriptions. This is not very surprising if we look at the dedications made by men, which also often omit this information: only in a few cases are their functions mentioned. [23] It appears that the information on the profession or status of the dedicators, either female or male, is considered as secondary in the votive context. The same can be said of the affiliation to tribes or cultic associations, which are less frequently mentioned in our inscriptions than in the case of construction and honorific inscriptions or the brief legends written on the Palmyrene tesserae. Moreover, votive dedications refer to a private "salvation". [24] In this context, the presence or absence of information concerning the family or professional affiliation is rather due to the private choice of the male or female dedicator, who does not have to specify to which tribe or association he or she belongs. It simply pertains to an individual religious experience.

The text PAT 1434 with the formula "Blessed his name forever", dated from $165 A D$, specifies that the female dedicator named Tadel was a freedwoman (bnt hry) of Bassos, son of Malku. We know nothing more about her, regarding her family affiliation (for instance whether she was married or had children). As for a freedman or a freedwoman, we do not have any further affiliation, only the name of their former master and his family.

As the examples show, women might act alone as dedicants, but also as conjoint dedicators together with their husbands or other family members. They are sometimes the beneficiaries of the dedications expressed by the prayers containing the formula "for the life of... (' hyy...)" studied by K. Dijkstra. [25] These prayers are the request for an "extension" of the divine grace, once experienced by dedicants, to other members of the households: mothers, sisters, wives, etc. - for the female part of the families [26] - as well as to the male members: brothers, fathers, uncles, [27] sons, etc.

"For the life" is the most popular reason for dedications. Some of the texts such as inscription PAT 1911 give a more elaborated reason for greeting the favourable deity while omitting the expression "for the life of...". This particular text was dedicated by the whole family - husband and wife, their children and the entire household - to "blessed his name forever" because "they called him in distress ( $\left.b^{\prime} q^{\prime}\right)$ and he answered in tranquillity (brwh')". This motive is well attested in ancient religious literature, such as Psalms and Mesopotamian prayers. [28] Distress is sometimes explained as a serious sickness or a sudden death. In another Palmyrene text, PAT 0065, offered by a woman, we read that she invoked "in the darkness" a god called "Lord of all Living Creatures and whose name is blessed forever". Unfortunately, the most interesting passages of this inscription are damaged. Another dedication is made by parents for their son [29] because of his sickness, and the ex-voto might be a testimony of healing. Nevertheless, this must remain an assumption since the text is very short and does not provide any further detail. The text PAT 2635 is a dedication
[22] STARK 1971.

[23] There are a few mentions of priests ( $k m r)$, apkallusages ('pkl) and two mentions of epimeletes. PAT: 0410, 0411.

[24] Moralee 2004, p. 3.
[25] DiJKSTRA 1995.

[26] KUBiaK 2013, p. 232.

[27] There are no references to aunts.

[28] KUBIAK 2016, p. 340.

[29] HVIDbeRG-HANSEN 1998, n. 129. 
made by a husband and his wife, to "blessed his name forever, good and merciful" on the occasion of being saved (WPȘ[YHWN___). [30] F. Briquel-Chatonnet, who first edited this text, reads this fragment "parce qu'il a ouvert son ventre", according to Judeo-Aramaic examples. [31] The notion of saving, even if not popular in Palmyra (this is the first evidence of this notion in the entire Palmyrene epigraphy [32]), corresponds well to the idea of making votive offerings in the aftermath of a rescue from a troubling situation. [33]

\section{FEMALE SUPPORT FOR CONSTRUCTIONS IN CULTIC PLACES}

Women do not only offer small altars, as mentioned above, but they also fund the construction of parts of temples in Palmyra. Two inscriptions from the temple of Baalshamin (fig. 2), dated from the first half of the $1^{\text {st }}$ c. CE (23 and $52 \mathrm{CE}$ ), mention women who participated, probably by donating money, in constructions of the sanctuary. In the first one, text PAT 0167, three women dedicate two columns for Baalshamin, "the good god" ( 'Ih'th'):
"In the month Kanun, year $23 \mathrm{CE}$, Attai and Shabhai, daughters (bnt) of Shahra and Atta, daughter (brt) of Pardash offered ( $q$ rbw) these two columns ( 'mwdy' 'In tryhwn) for Baalshamin, the good god (' $/ h$ ' th') for their lives (hyyhn) and the lives of their children (bnyhn i.e. sons) and brothers ('hyhn)." They did that in the intention of well-being, for the protection of the life of their children and siblings. The second text, PAT 0168, commemorates an offering of a column by a woman called Amtallat, daughter (brt) of Baraa, son of Atenatan, who (the woman) is from the tribe (phd [34]) of the daughters of Mîta [35] (bnt myt', female counterpart of bny myt') to the same deity as in the previous dedication but qualified as "the good and rewarding god" ( ' $/ h$ ' $t b$ ' $\left.w s ̌ k r^{\prime}\right)$. These epithets also appear in the dedications made by Palmyrene men. [36] The inscription PAT 0170, dated from $67 \mathrm{CE}$, mentions a similar offering to the donation of Attai made by a man called Malku, son ( $b r$ ) of Alaysha, son of Malku from the tribe ( $p h d$ ) of Maazin to Baalshamin and Durahlun (drh/wn), labelled "the good and rewarding gods" ('Ihy' thy' wškry').

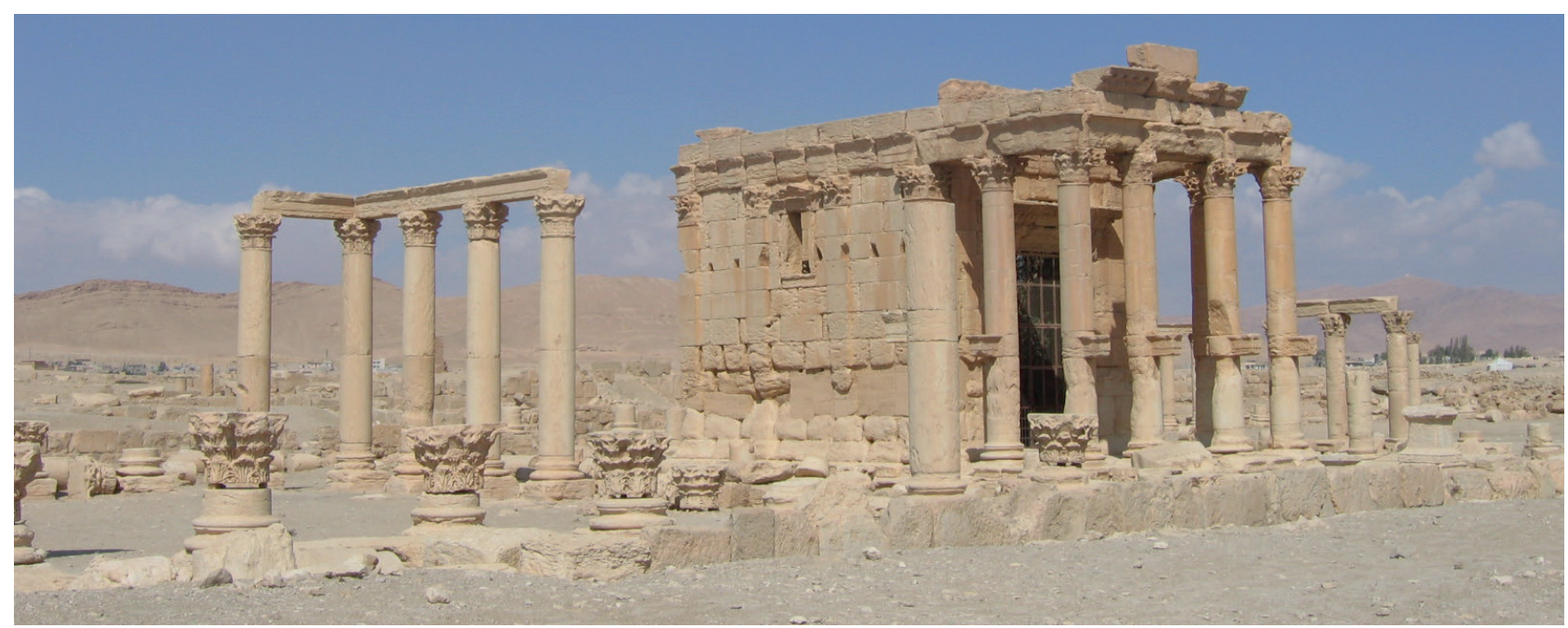

Fig. 2 : Temple of Baalshamin Palmyra.

[30] Here is our new translation of this text: "Blessed his name forever, good and merciful. In thanksgiving dedicated by Natan, son of Worod and Belta, his wife, who invoked him (i.e. the god) and he saved them".

[31] BRIQUel-ChATONNET 1991, p. 85-86.

[32] The verb pșy in a sense of saving is attested in many dialects of Aramaic (also in the Parthian Aramaic of Assur from the same time as the cited Palmyrene inscription). See http://cal.huc.edu (opened on 18/02/21). The notion of rescuing is very appropriate in the votive inscription. [33] For further details on the question of salvation in the context of the ancient dedications see Moralee 2004. [34] Or assembly. The Aramaic word phd can have a double meaning, usually translated in the Palmyrene studies as "tribe", see among others GAWLIKowsKi 1973, p. 38, with his theory of 4 civic tribes which concern the tribe of Bene
Mîta and Bene Maazin, and Yon 2002, but it can borrow its meaning from the Akkadian puhru, "assembly". This new interpretation could open a discussion about cultic groups in Palmyra, an issue currently under study by the present author. The names of the "tribes" seem to be very meaningful (bny kmr' - members of priesthood, bny syrt' - members of the caravans). Their appearance on tesserae is puzzling because it leads to a conclusion that these are either special districts or associations (cultic or civic). The question of the social structure in Palmyra is a different research problem which needs to be revised (paper in preparation).

[35] Beside the interpretation of Mita as the name of the great ancestor, the founder of the tribe, the Aramaic mita literally means "dead" or "mortals".

[36] KUBIAK 2013, p. 229-230. 
Beside the votive context, the text PAT 0315, probably dated from 17 CE (the date is partly damaged), attests the name of a woman Atem ('t'm), daughter (brt_?) of? and wife ('t $t$ ) of Bolha whose tribal affiliation is not mentioned. This inscription tells us that Atem was offered ( $q y m$ ) a statue (șlmt') by Aglibol and Malakbel, the gods (labelled 'Ihy'), and the tribe of Bene Komare (bny kmr' lit.: 'the assembly of priests' (?)). However, the text does not specify the reason for this commemoration. We shall only deduce that she made some kind of benefaction for the gods, maybe the foundation of a construction within the cultic place or a valuable offering to the gods. It could also have been a service for the temple. Another woman equally honoured by the

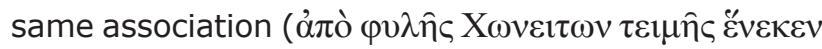

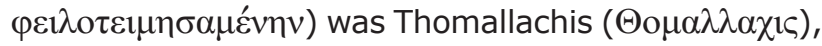
daughter of Haduddan, son of Iarhibola (A $\delta \delta$ ov $\delta \alpha v 0 v$

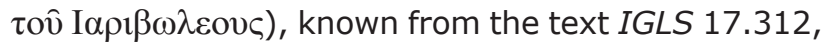

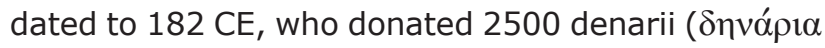
$\left.\delta 1 \sigma \chi \varepsilon \varepsilon^{\prime} \lambda 1 \alpha \pi \varepsilon v \tau \alpha \kappa o ́ \sigma 1 \alpha\right)$ for the construction of the baths of Aglibol and Malakbel, the gods (

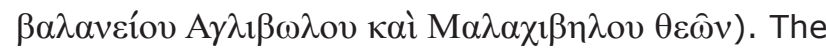
sum that she gave is outstanding: a big amount of money, managed independently by a Palmyrene woman. According to Jean-Baptiste Yon, she was a descendant from a great Palmyrene noble family. [37] Both women, Atem and Thomallachis, are honoured alone, in a similar way as men. They do not act with the help of a male representant, but in full autonomy. Unfortunately, we do not know anything more about them, nor about the specific part they played in the cult. They undoubtedly belonged to the Palmyrene nobility.

\section{PRIESTHOOD IN PALMYRA: ONLY FOR MEN?}

We do not know if any of the mentioned Palmyrene women was a priestess, since none of the inscriptions mention such a title/function/position. In fact, the form $k m r t^{\prime}$, feminine form of kmr' (priest), is not attested in the Palmyrene sources. In my opinion it would be premature and misleading to conclude that religious functions were only held by men in Palmyra. However, this absence from the written record is striking, especially concerning the great amount of available sources (more than 2500 inscriptions). Neither funerary inscriptions nor funerary reliefs indicate a cultic function held by a Palmyrene woman. The texts PAT 0167 and 0168 , mentioned in the previous section, differ from each other by the reference to a tribal affiliation (bnt myt'). This tribe (or association) is the only one mentioned in combination with the name of a woman. This raises the question, not only of the structure of the Palmyrene society and its tribal division, but also of the role of the women belonging to these groups. Apart from the benefactors of the sanctuary, who were these women assembled in the bnt myt'? Could it be that with the bnt myt' a collegium of female cultic servants of some sort existed beside the bny myt' as the male group?

Jean-Baptiste Yon remarks that both the Greek and Semitic worlds have some sort of female priesthood functions, but the sources from Palmyra do not refer to any of them. [38] He underlines a case in Hatra, close to Palmyra in time ( $2^{\text {nd }}-3^{\text {rd }}$ c. CE) and culture, where a honorific statue depicts a priestess of Isharbel with unveiled face, holding the veil in her right hand and the left raised in the greeting gesture. [39] Male priests are easily recognizable by the special hat they wear (called modius by scholars), [40] but we have no iconographic data combined with inscriptions that could demonstrate the admittance of women to priesthood according to their clothing, despite some attempts. [41] Women do not appear in the legends of the tesserae, an observation which is interpreted as a proof of their absence in the banquets - if we see these little objects as tickets for the cultic meals. [42] None of these small tokens, usually made of clay, represents a female figure as a worshipper or priestess. On this category of objects, the female figures are exclusively goddesses.

However, the religious art of Palmyra may help us to understand other activities (beside donations and dedications) and roles of women in the cults of Palmyrene gods. The new interpretation we would like to propose here, concerning two reliefs to be dated probably from the $1^{\text {st }} \mathrm{C}$. CE and belonging to the two important Palmyrene cultic centres such as the temple of Bel and the temple of Allat, sheds light on the place of women in rituals. The first, coming from the temple of Bel, is a monumental bas-relief situated formerly on the frieze part of the sanctuary. It represents five veiled women watching a procession with a camel bearing a palanquin and donkey, and three women veiled in the same way in front of the gods, in the welcoming and blessing attitude. The second relief, from the temple of Allat, represents six women, veiled in the same fashion, also accompanying a camel with a palanquin. Each of them

[37] Yon 2002, p. 280.

[38] Yon 2018, p. 184-185.

[39] For the inscription see BEYER 1998.

[40] Recent work on the priests of Palmyra: see RAJA

2017 together with the discussion on the term "modius" used for the priestly hat.

[41] Yon 2018, p. 184-185, FinLayson 2013, p. 64.

[42] For recent studies on tesserae from Palmyra see RAJA 2016, RAJA 2020, KUBIAK-SCHNEIDER in press. 
holds her veil with her right hand on the height of her chin. Their hands are also hidden. [43] Anna Sadurska describes this representation as follows: "voilées depuis le sommet de la tête jusqu'aux chevilles, les visages et les mains cachés dans les plis denses de l'étoffe" [44] (fig. 3). This scene differs from the representation of women on the votive altars with the formula "Blessed his name forever" mentioned at the beginning of this paper. Some of these objects bear a depiction of the female dedicant, barefoot, standing with raised arms and unveiled face but covered head. The male head is mostly uncovered. Only the priests are represented with the head covered with a cap indicating their position in the cultic sphere. Men are also pictured barefoot in front of the gods.

The difference in representing women and men in art results foremost from the character of the two rites. Both, a relief in the temple of Bel and an image of women from the temple of Allat, show a procession pertaining to a big religious festival, while the image of the adoration and offering of incense on the top of an altar represents an individual in context of prayer and praise. Nevertheless, it raises a question: who are the women attending the procession? Are they private individuals who attend this ritual or did they fulfil a special cultic function? Did Palmyrenes praise their gods in this manner?

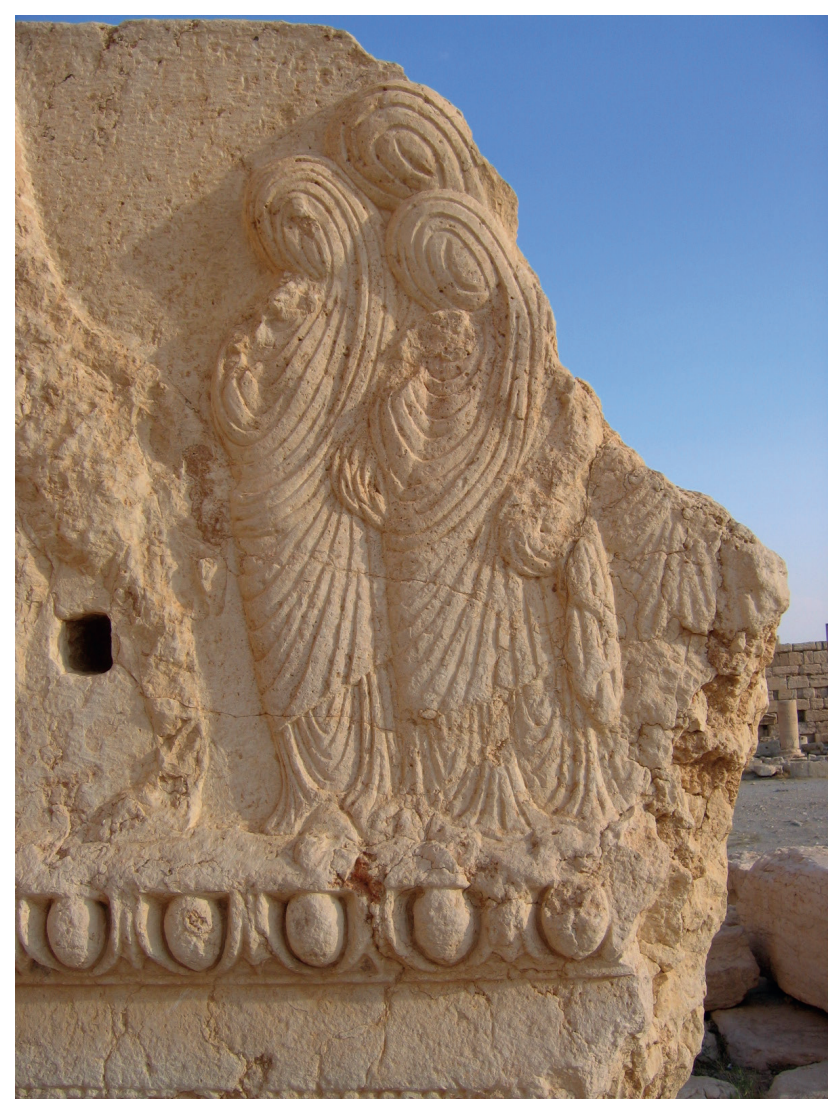

Fig. 3 : Palmyra, temple of Bel, relief of procession.
These women, from both the first and second images, were either part of the public who assisted their gods in the processions or played a specific cultic role. We know from $1^{\text {st }}$ millennium BCE Mesopotamia that there was a festival of redûtu, the day of the goddess' procession which was a cultic service managed by married women during the New Year festival. [45] The crossbeams reliefs from the temple of Bel can relate to the New Year celebration showing the most important religious event in Palmyra. [46] We do not know how religious ceremonies were exactly performed in Palmyra, but thanks to these reliefs we spot a procession of veiled women. Maybe there was a special regulation concerning the female cultic servants (priestesses?) who needed to be entirely covered in the public festivals? Due to a lack of evidence, all these references could be hypothetical, but raise new questions about the participation of women in the rituals in Palmyra.

\section{CONCLUSION}

Women are present in the Palmyrene religious life, even if their professional status such as priestesses, singers or musicians is not stated explicitly. In most of the cases they are called daughters and wives of a male relative, but sometimes their affiliation is not specified. Palmyrene men also identify themselves by their affiliation, nevertheless they only identify themselves as the son of a male member of the family, which highlights the patrilinear character of the society. We saw that women dedicate to the city gods in the same way as men do; they also receive honours in the same way as Palmyrene men: with a decree and a statue set up in the public space, although the number of these depictions is small. Moreover, they act themselves for their own well-being and for the well-being of their families, and they can be the addressees of graces in the dedications by others. They belong to the upper class of Palmyrene society, and are therefore able to offer a large sum of money for the construction of cultic buildings, which shows that they independently managed valuable goods.

What is most striking is the fact that the dedications made by women are addressed only to the male divinities. Moreover, female names or images appear within the context of the great Palmyrene gods: Baalshamin, Bel, Aglibol, Malakbel and Allat. On the one hand, in

[43] GaWLikowski 2019, p. 212 (with the image).

[44] SADURSKA 1991-1992, p. 101.

[45] OSHIMA 2007, p. 355

[46] DALLey 1995. 
the dedicatory context, standing in front of the divinity and praising his name, a woman's face was unveiled. On the other hand, on reliefs referring to public ceremonies, their face and head are entirely covered. Does it mean that the entirely covered face displays a status not necessarily of a married woman, but of a membership in the priestesshood and their special function during the ceremonies? This image could be related to a specific function. However, there were also some honorific statues, unfortunately not preserved nowadays, but thanks to similar material from Hatra, we suppose that statues of women could depict them with their face uncovered. Nevertheless, the corpus of the Palmyrene inscriptions is not yet closed, the lack of other information about a religious role of women in Palmyra can be just a silence of our sources and we cannot exclude that new inscriptions or reliefs will bring more light on the subject.

\section{THANKS}

I would like to thank here the organizers Thomas Galoppin and Adeline Grand-Clément for the invitation to the workshop which was a methodological challenge for me. I am particularly grateful to Thomas Galoppin, Adeline Grand-Clément, Corinne Bonnet and Stella Georgoudi for all constructive questions and hints on how to treat the Palmyrene material through the gender approach. Furthermore, I want to thank Bernhard Schneider for improving my English. Moreover, our title was chosen so as to avoid confusion with the recent paper of S. F. Klaver entitled "The participation of women in the religious life of Palmyra", see KLAVER $2019 a$. It was available to me at a late stage in the writing of the present article.

PAT = Cussini Eleonora, Hillers Dillbert R., 1999, Palmyrene Aramaic Texts, Baltimore.

BeYer, Klaus, 1998, Die aramäischen Inschriften aus Assur, Hatra und dem übrigen Ostmesopotamien, Göttingen. Briquel-Chatonnet, Françoise, 1991, « Un petit autel palmyrénien », Semitica 40, p. 83-87.

Cussinr, Eleonora, 2005, « Beyond the Spindle: Investigating a Role of Palmyrene Women », in Eleonora Cussini (ed.), A Journey to Palmyra. Collected Essays to Remember Delbert R. Hillers, Leiden - Boston - Köln, p. 26-43.

Dalley, Stephanie, 1995, «Bel at Palmyra and Elsewhere in the Parthian Period », ARAM 7, p. 137-151.

Dijkstra, Klaus, 1995, Life and Loyalty. A Study in the Socio-Religious Culture of Syria and Mesopotamia in the Graeco-Roman Period Based on Epigraphical Evidence (RGRW 128), Leiden.

Dirven, Lucinda, 1999, The Palmyrenes of Dura-Europos. A Study of Religious Interaction in Roman Syria (RGRW 138), Leiden - Boston - Köln.

Duchateau, Marie-Emmanuelle, 2013, Les divinités d'Europos-Doura. Personnalité et identité (301 av. n.è. - 256 de n.è.), Paris.

Finlayson, Cynthia, 2013, « New Perspectives on the Ritual and Cultic Importance of Women at Palmyra and DuraEuropos: Processions and Temples », Studia Palmyrenskie 12, p. 61-85.

GawlikowskI, Michal, 1973, Le temple palmyrénien. Étude d'épigraphie et de topographie historique (Palmyre VI), Warsaw.

Gawlikowski, Michal, 2019, Le sanctuaire d'Allat à Palmyre (PAM Studies 8), Warsaw.

HeYn, Maura. K., 2019, «The Significance of the Orans Pose in Palmyrene Art », in Rubina Raja (dir.), Revisiting the Religious Life of Palmyra (Contextualizing the Sacred 9), Turnhout, p. 153-160.

Hvidberg-Hansen, Finn Ove, 1998, The Palmyrene Inscriptions: Ny Carlsberg Glyptotek, Kobenhavn.

IntAgliata, Emanuele, 2018, Palmyra after Zenobia AD 272-750. An archaeological and historical reappraisal, Oxford. KaIzer, Ted, 2002, Religious Life of Palmyra: a study of the social patterns of worship in the Roman period (Oriens et Occidens 4), Stuttgart. 
KaIzer, Ted, 2019, Patterns of Worship at Palmyra: Reflections on Methods and Approaches, in: Rubina Raja (dir.), Revisiting the Religious Life of Palmyra (Contextualizing the Sacred 9), Turnhout, p. 7-24.

Klaver, Sanne F., 2019a, «The Participation of Palmyrene Women in the Religious Life of the City », in Signe Kraag \& Rubina Raja (eds.), Women, Children and the Family in Palmyra (Palmyrene Studies 3), Copenhagen, p. $157-167$.

KLAVer, Sanne F., 2019b, Women in Roman Syria. The cases of Dura-Europos, Palmyra, and Seleucia on the Euphrates, unpublished PhD thesis.

KraG, Signe, 2017, «Women in Palmyrene Religion and Religious Practices », in Cecile Brons \& Marie-Louise Nosch (eds.), Textiles and Cult in the Ancient Mediterranean, Oxford, p. 230-240.

Kubiak, Aleksandra, 2013, « Des "dieux bons" à Palmyre », Studia Palmyrenskie 12, p. 227-234.

KubiaK, Aleksandra, 2016, « The gods without names? Palmyra, Hatra, Edessa », Aram 28, p. 337-348.

Kubiak-Schnerder, Aleksandra, 2021, Des dédicaces sans théonyme de Palmyre : Béni (soit) son nom pour l'éternité (Religions of the Graeco-Roman World 197), Leiden.

Kubiak-Schneider, Aleksandra, in press, « Palmyrene Tesserae in the Context of Temple Administration », in Rubina Raja (ed.), Small Stuff of Palmyrenes. Coins and Tesserae from Palmyra (proceedings of the international conference) (Palmyrensk Studies).

LINDSEY, Linda L., 2015, «The sociology of gender», in Gender roles: a sociological perspective, Boston, p. 4 (open access online https://web.archive.org/web/20150924070249/ http://www.pearsonhighered.com/assets/hip/us/ hip us pearsonhighered/samplechapter/0132448300.pdf, accessed on 03/08/20).

Moralee, Jason, 2004, For salvation's sake: provincial loyalty, personal religion, and epigraphic production in the Roman and late antique Near East, New York.

OsнrmA, Takayoshi, 2007, « The Babylonian God Marduk », in G. Leick (ed.), The Babylonian World, New York London, p. 348-360.

RAJA, Rubina, 2015, « Cultic dining and religious patterns in Palmyra. The case of the Palmyrene banqueting tesserae », in S. Faust, M. Seifert, L. Ziemer (eds.), Festschrift für Inge Nielsen. Gateway 3. Hamburger Beiträge zur Archäologie und Kulturgeschichte des antiken Mittelmeerraumes, Aachen, p. 181-200.

RAJA, Rubina, 2016, «In \& Out of Contexts: Explaining Religious Complexity through the Banqueting Tesserae from Palmyra », Religion in the Roman Empire 2, 3, Tübingen, p. 340-371.

RAJA, Rubina, 2017, « To be or not to be depicted as a priest in Palmyra. A matter of representational spheres and societal values », in T. Long \& A. H. Sorensen (eds.), Positions and Professions in Palmyra (Scientia Danica H, 4.9), Viborg, p. 115-130.

RAJA, Rubina, 2020, «Dining with the gods and the others: the banqueting tickets from Palmyra as expressions of religious individualization », in Martin Fuchs, Antje Linkenbach, Martin Mulsow, Bernd-Christian Otto, Rahul Bjørn Parson \& Jörg Rüpke, Religious Individualisation. Historical Dimensions and Comparative Perspectives, Berlin/Boston, p. 243-255. Sadurska, Anna, 1991-1992, «Les rôle (sic) des femmes dans le culte à Palmyre (recherche iconographique) », Vox Patrum 11-12, p. 101-104.

SchörNer, Günther, 2003, Votive im römischen Griechenland. Untersuchungen zur späthellenistischen und kaiserzeitlichen Kunst- und Religionsgeschichte, Wiesbaden Altertumswissenschaftliches Kolloquium 7, Stuttgart.

StARK, Kurt, 1971, Personal Names in Palmyrene Inscriptions, Oxford.

Van der Mieroop, Marc, 2003, «Reading Babylon », American Journal of Archaeology 107/2, p. 257-275.

Yon, Jean-Baptiste, 2002, Les notables de Palmyre, Beyrouth.

Yon, Jean-Baptiste, 2018, «Femmes de Palmyre », in S. Lalanne (ed.), Femmes grecques de l'Orient romain (Dialogues d'histoire ancienne Suppl. 18), Besançon, p. 183-203. 